\title{
Różnice i podobieństwa między cłami a opłatami o skutku równoważnym do ceł
}

\section{Wprowadzenie}

Zgodnie z art. 28 ust. 1 Traktatu o funkcjonowaniu Unii Europejskiej ${ }^{2}$ unia celna stanowi podstawę Unii Europejskiej, rozciągając się na całą wymianę towarową, a jednocześnie obejmując „zakaz stosowania ceł przywozowych i wywozowych między państwami członkowskimi oraz wszelkich opłat o skutku równoważnym, jak również przyjęcie wspólnej taryfy celnej w stosunkach z państwami trzecimi”. Powołana regulacja prawna sugeruje zatem co najmniej dwa elementy wyznaczające aspekt wewnętrzny i zewnętrzny unii celnej. Po pierwsze, obejmuje ona dwa zakazy, tj. zakaz pobierania w stosunkach między państwami członkowskimi UE ceł przywozowych, wywozowych oraz zakaz pobierania opłat o skutku do nich podobnym (tzw. aspekt wewnętrzny unii celnej). Po drugie, Unia Europejska stosuje Wspólną Taryfę Celną (tzw. aspekt zewnętrzny) wobec wszystkich towarów pochodzących z państw trzecich. Jak wynika z powołanego wyżej przepisu, organy celne nie mogą pobierać $w$ ramach wymiany towarowej pomiędzy państwami członkowskimi ceł oraz opłat o równoważnym cłom skutku. Wszystkie wymienione typy świadczeń publicznoprawnych, choć są związane ściśle $\mathrm{z}$ wymianą towarową, różnią się charakterem prawnym i pełnionymi funkcjami, a ponadto regulowane są odrębnymi przepisami prawnymi.

Powyższe ustalenia rzutują na przedmiot rozważań zawartych w niniejszym opracowaniu i odpowiadają zakreślonemu jego tytułem polu badawczemu. Analiza regulacji prawnych skupiać się będzie na wskazaniu różnic i podobieństw tych dwóch form świadczeń pobieranych w obrocie towarowym, tj. ceł i opłat o równoważnym cłom skutku. Podjęcie takich rozważań jest tym bardziej uzasadnione, że w doktrynie prawa celnego oraz

\footnotetext{
${ }^{1}$ Dr Adam Drozdek, starszy wykładowca w PWSZ im. rtm. W. Pileckiego w Oświęcimiu, adwokat, agent celny.

${ }^{2}$ Wersja skonsolidowana Dz.Urz. UE C 202, s. 47, dalej TFUE.
} 
w judykaturze wyrażenie „opłaty o równoważnym cłom skutku”3 nie jest jednolicie rozumiane.

\section{Instytucja cła - istota i charakter prawny}

Obowiązek stanowienia i nałożenia cła wynika $\mathrm{z}$ regulacji unijnego prawa celnego. Artykuł 5 ust. 20 i 21 obowiązującego od 1 maja 2016 r. rozporządzenia nr 952/2013 ${ }^{4}$ zawiera legalną definicję należności celnych przywozowych i wywozowych, zgodnie z którą „należności celne przywozowe oznaczają należności celne płatne przy przywozie towarów”. Z kolei „należnościami celnymi wywozowymi są należności celne płatne przy wywozie towarów". A zatem brzmienie powołanych regulacji prawnych pozwalają przyjąć, że unijne regulacje celne nie wymieniają z nazwy ceł oraz opłat o równoważnym cłom skutku, jak to miało miejsce w nieobowiązującym już wspólnotowym kodeksie celnym ${ }^{5}$. Pomimo tak bardzo ogólnej definicji należności celnych przywozowych i wywozowych, w literaturze przedmiotu podkreśla się, że należności celne przywozowe i wywozowe obejmują swym zakresem cła oraz opłaty o równoważnym cłom skutku, pobierane od towarów pochodzących z państw trzecich ${ }^{6}$.

Podstawowe znaczenie posiada również rozporządzenie Rady nr 2658/87 z dnia 23 lipca 1987 r. w sprawie nomenklatury taryfowej i statystycznej oraz w sprawie Wspólnej Taryfy Celnej ${ }^{7}$. Zawarta została w nim taryfa cel-

\footnotetext{
${ }^{3} \mathrm{~W}$ literaturze przedmiotu wskazuje się, że opłaty o równoważnym cłom skutku zaliczane są do instrumentów pozataryfowych, czyli są to wszystkie środki przedsięwzięte przez państwo (grupę państw), które w efekcie wywierają ograniczający wpływ na handel międzynarodowy (A. Kuś, Publicznoprawne pozataryfowe i parataryfowe instrumenty reglamentacji obrotu towarowego z zagranica, Bydgoszcz-Szczecin-Lublin 2006, s. 57 i n.).

${ }^{4}$ Rozporządzenie Parlamentu Europejskiego i Rady (UE) nr 952/2013 z dnia 9 października 2013 r. ustanawiające unijny kodeks celny (wersja przekształcona), Dz.Urz. UE L 269, s. 1 ze zm., dalej UKC.

${ }^{5}$ Rozporządzenie Rady (EWG) nr 2913/92 z dnia 12 października 1992 r. ustanawiające Wspólnotowy Kodeks Celny, Dz.Urz. UE L 302, s. 1, polskie wydanie specjalne z 2004 r., rozdz. 2, t. 4, s. 307 ze zm., dalej WKC. Zgodnie z art. 4 pkt 10 WKC należnościami celnymi przywozowymi były: 1) cła i opłaty o równoważnym skutku, należne przy przywozie towarów, 2) opłaty przywozowe ustanowione w ramach wspólnej polityki rolnej lub odrębnych przepisów mających zastosowanie do niektórych towarów, uzyskanych $\mathrm{w}$ wyniku przetworzenia produktów rolnych. Natomiast zgodnie z art. 4 pkt 11 WKC należnościami celnymi wywozowymi były: 1) cła i opłaty o równoważnym skutku, należne przy wywozie towarów, 2) opłaty wywozowe stanowione w ramach wspólnej polityki rolnej lub odrębnych przepisów mających zastosowanie do niektórych towarów, uzyskanych w wyniku przetworzenia produktów rolnych.

${ }^{6}$ Szerz. zob. A. Drozdek, Charakter prawny cła jako daniny publicznej w krajowym i unijnym prawie celnym, Szczecin 2017, s. 104-106.

${ }^{7}$ Dz.Urz. WE L 256, s. 1. Od 1 stycznia 2011 r. obowiązuje rozporządzenie Komisji (UE) nr 861/2010 z dnia 5 października 2010 r., zmieniające załącznik nr I do rozpo-
} 
na Unii Europejskiej, na podstawie której obliczane i pobierane jest cło. Unijne przepisy prawa celnego regulujące międzynarodowy obrót towarowy zostały uzupełnione przez krajowe regulacje państw członkowskich. Państwa zostały upoważnione do stanowienia przepisów krajowych normujących problematykę celną tylko w niektórych przypadkach. W Polsce obowiązującym aktem prawnym, który uzupełnia regulacje unijnego kodeksu celnego, jest ustawa z dnia 19 marca 2004 r. - Prawo celne 8 .

Instytucja cła należy do jednej z podstawowych danin publicznych pobieranych $\mathrm{w}$ obrocie towarowym $\mathrm{z}$ zagranicą oraz jest świadczeniem najbardziej skodyfikowanym i ujednoliconym spośród innych form danin publicznych pobieranych $\mathrm{w}$ wymianie handlowej $\mathrm{z}$ zagranicą. Jednakże podkreślenia wymaga fakt, że krajowe i unijne regulacje celne nie zawierają legalnej definicji pojęcia "cło”. W doktrynie prawa instytucja cła jest definiowana jako świadczenie, które ustalane i pobierane jest na podstawie taryfy celnej od podmiotów dokonujących obrotu towarowego z zagranicą, w związku z przemieszczaniem się towaru przez granicę celną państwa lub grupy państw tworzących unię celną9

Analizując to zagadnienie, należy wskazać, że zgodnie z orzecznictwem Trybunału Konstytucyjnego cło należy do kategorii danin publicznych. W wyroku z dnia 6 grudnia 2006 r., SK 25/05 Trybunał stwierdził, że cło jest świadczeniem pieniężnym o charakterze daninowym, którego pobór związany jest $\mathrm{z}$ faktem przywozu, wywozu lub przewozu towarów przez granicę obszaru celnego, pokrywającego się z reguły z obszarem państwa ${ }^{10}$. Podobny pogląd prezentowany jest również $\mathrm{w}$ orzecznictwie sądowoadministracyjnym. Na przykład w wyroku z dnia 2 grudnia 2015 r., I GSK 793/14, NSA sformułował tezę, zgodnie z którą cło jest świadczeniem pieniężnym o charakterze daniowym. Zdaniem Sądu pobór cła należy wiązać tylko i wyłącznie z faktem przywozu, wywozu lub przewozu towarów przez granicę obszaru pokrywającego się na ogół z obszarem państwa ${ }^{11}$. Z kolei w wyroku z dnia 28 sierpnia 2008 r., III SA/Po 158/08 WSA w Poznaniu

rządzenia Rady (EWG) nr 2658/87 w sprawie nomenklatury taryfowej i statystycznej oraz wspólnej taryfy celnej, Dz.Urz. UE L 284, s. 1. W celu wykonania przepisu delegacyjnego Komisja przyjmuje każdego roku rozporządzenie przedstawiające pełną wersję Nomenklatury Scalonej wraz ze stawkami celnymi. Rozporządzenie takie każdorazowo aktualizuje załącznik do rozporządzenia. Jest ono publikowane nie później niż 31 października danego roku w „Dzienniku Urzędowym Unii Europejskiej”. Stosuje się je od 1 stycznia roku następnego.

${ }^{8}$ Por. art. 1 ustawy z dnia 19 marca 2004 r. - Prawo celne, tekst jedn.: Dz.U. z 2018 r. poz. 167 ze zm.

${ }^{9}$ A. Drozdek, Definicja cła-postulat nowelizacji przepisów prawa celnego, „Monitor Prawa Celnego i Podatkowego" 2015, nr 11 (244), s. 390-395.

${ }^{10}$ OTK-A 2006, nr 11, poz. 169, LEX nr 221524.

${ }^{11}$ LEX nr 1999860. W szerszym ujęciu cła należy wiązać z dopuszczeniem towaru do obrotu po przekroczeniu granicy celnej - por. wyrok WSA we Wrocławiu z dnia 11 czerwca 2015 r., I SA/Wr 797/15, LEX nr 1816998. 
wskazał, że cło jest immanentnym elementem taryfy celnej UE ${ }^{12}$. Oznacza to, że w przypadku przywozu towaru z zagranicy na terytorium celne UE lub wywozu towarów poza granicę celną UE cło zostaje obliczone na podstawie stawek celnych zawartych we Wspólnej Taryfie Celnej, która jest ustalana przez Radę UE na wniosek Komisji. To właśnie na jej podstawie ustalane i pobierane są jednakowe cła na poszczególne kategorie towarów sprowadzanych z państw trzecich do państw członkowskich Unii.

Powyższe tezy znajdują także odzwierciedlenie w literaturze przedmiotu, gdzie wielokrotnie wskazywano, iż cło jest daniną publiczną. I tak np. według B. Brzezińskiego cło należy do kategorii danin publicznych pobieranych w związku z przemieszczaniem towarów przez granicę państwa $^{13}$. Z kolei K. Lasiński-Sulecki i W. Morawski twierdzą, że przedmiotem cła jako daniny publicznej jest wprowadzenie lub wyprowadzenie towaru z obszaru celnego ${ }^{14}$. Na tle zaprezentowanych rozważań prawnych zauważyć należy, że instytucja cła stanowi obecnie przede wszystkim ważne narzędzie taryfowe polityki handlowej z zagranicą, jak również jest jednym $\mathrm{z}$ dochodów związku publicznoprawnego, tj. Polski oraz Unii Europejskiej ${ }^{15}$.

W świetle przedstawionych stanowisk judykatury i doktryny należy uznać, że cło jako świadczenie pieniężne należy niewątpliwie do kategorii danin publicznych. Pobierane jest na rzecz podmiotów publicznych (państwa, Unii Europejskiej) w związku z dopuszczeniem towaru do obrotu po przekroczeniu granicy celnej. Publicznoprawny charakter obowiązku jego uiszczenia wynika przede wszystkim z unijnego prawa celnego, gdzie zostały określone wszystkie elementy konstrukcyjne cła jako daniny publicznej.

$\mathrm{W}$ tym miejscu należy jednak zauważyć, że o istocie cła decyduje również fakt, iż stanowi ono integralną część systemu reglamentacji wymiany handlowej z zagranicą, a pełniona przez nie funkcja fiskalna może zostać $\mathrm{z}$ łatwością uzupełniona przez funkcję protekcjonistyczną. Pierwsza $\mathrm{z}$ wymienionych funkcji wyraża się w dostarczaniu dochodów związkowi pu-

${ }^{12}$ LEX nr 501340.

${ }^{13}$ B. Brzeziński, Pojęcie i rodzaje danin publicznych [w:] Prawo finansowe, W. Wójtowicz, B. Brzeziński, T. Dębowska-Romanowska, M. Kalinowski (red.), Warszawa 2000, s. 185, 187.

${ }^{14}$ K. Lasiński-Sulecki, W. Morawski, Komentarz do art. 30 [w:] Traktat o funkcjonowaniu Unii Europejskiej. Komentarz, t. I, Art. 1-89, D. Miąsik, N. Półtorak, A. Wróbel (red.), LEX 2012.

${ }^{15}$ Zgodnie z treścią art. 2 ust. 1 lit. a oraz ust. 3 decyzji Rady nr 2014/335/UE, Euratom z dnia 26 maja 2014 r. w sprawie systemu zasobów własnych Unii Europejskiej (Dz.Urz. UE L 168, s. 105) od 1 października 2016 r. organy celne przekazują 80\% pobranego cła do budżetu Unii Europejskiej, co oznacza, że z racji funkcjonowania unii celnej pobierane przez polskie organy celne cło jest przede wszystkim dochodem budżetu Unii Europejskiej, a Polska na poczet kosztów poboru zatrzymuje tylko 20\% kwoty cła. Szerzej zob. A. Drozdek, Analiza normatywna dochodów budżetowych uzyskiwanych $z$ cet w polskim porządku prawnym, „Prawo Budżetowe Państwa i Samorządu” 2017, nr 2 (5), s. 29 i n. 
blicznoprawnemu. Cel fiskalny stanowił w przeszłości i stanowi aktualnie jeden $\mathrm{z}$ podstawowych motywów pobierania ceł i w dużym stopniu przesądza o ich konstrukcji ${ }^{16}$. Z kolei druga funkcja - protekcjonistyczna - polega na ochronie gospodarki (rynku krajowego) przed napływem tanich towarów z zagranicy. Ma ona na celu zapewnienie możliwości rozwoju lub utrzymania produkcji krajowej. P. Witkowski wskazuje, iż funkcja ta realizowana jest przez wprowadzenie wysokich ceł ochronnych, antydumpingowych lub wyrównawczych. W rezultacie produkty importowane stają się droższe, a zatem mniej konkurencyjne na rynku krajowym, natomiast produkcja krajowa może być sprzedawana po niższych cenach niż towary importowa$n e^{17}$. W przypadku gdy towary objęte cłami nie są wytwarzane przez krajowych producentów, może nastąpić istotny spadek ich konsumpcji. Z kolei jeśli są produkowane w kraju, to wzrost cen towarów importowych może prowadzić do wzrostu produkcji ich krajowych odpowiedników.

W świetle powyższych ustaleń przyjąć należy, iż obecnie cło jako jedno ze źródeł dochodów budżetu państwa i Unii Europejskiej nie realizuje tylko i wyłącznie funkcji fiskalnej. O istocie cła jako daniny publicznej decyduje także realizowana przez nie funkcja ochronna, polegająca na ochronie rynku unijnego przed nadmiernym przywozem towarów pochodzących spoza obszaru Unii Europejskiej po cenach dumpingowych. Oznacza to, że obowiązek uiszczenia cła powstaje z mocy prawa, $\mathrm{z}$ chwilą przekroczenia granicy celnej państwa lub wejścia w posiadanie towaru celnego.

\section{Istota i charakter prawny opłat o równoważnym cłom skutku}

Podobnie jak w przypadku instytucji cła, przepisy unijnego prawa celnego, jak również krajowe prawo celne nie definiują terminu „opłaty o równoważnym cłom skutku”. Brak jest również określenia takich opłat przez Traktat o funkcjonowaniu Unii Europejskiej. W konsekwencji powoduje to, że niezbędne jest podjęcie próby określenia istoty tych opłat, co wiąże się ze wskazaniem roli, jaką pełnią one w obrocie towarowym z zagranicą.

$\mathrm{W}$ piśmiennictwie zostały podjęte próby zdefiniowania opłat o równoważnym cłom skutku, jak również określenie ich istoty oraz charakteru prawnego. I tak, zdaniem D. Lasoka, są to „opłaty pieniężne, niezależnie od ich wysokości, przeznaczenia i sposobu nałożenia, które są jednostronnie nakładane na towary krajowe lub zagraniczne w związku z faktem, że towary te przekraczają granicę, a które to opłaty nie są cłami w wąskim tego

${ }^{16}$ Por. P. Sawczuk, Przesłanki stosowania wydłużonego terminu powiadomienia dłużnika o kwocie długu celnego w świetle praktyki orzeczniczej Europejskiego Trybunatu Sprawiedliwości [w:] Prawo finansowe w warunkach członkostwa Polski w Unii Europejskiej. Księga pamiątkowa dedykowana profesor Wandzie Wójtowicz, A. Pomorska, P. Smoleń, J. Stelmasiak, A. Gorgol (red.), Lublin 2011, s. 399.

${ }^{17} \mathrm{P}$. Witkowski, Instytucje wspólnotowego prawa celnego w międzynarodowym obrocie towarowym, Chełm 2008, s. 60. 
słowa znaczeniu"18. Zbieżny pogląd z prezentowanym wyżej przedstawia A. Jędruszczak, która uważa, że opłatą o równoważnym cłom skutku należy nazwać każdą opłatę niewpisaną do taryfy celnej, a która pobierana jest jednostronnie przez związek publicznoprawny w związku z przekraczaniem granicy celnej przez towar ${ }^{19}$. Inni autorzy - K. Lasiński-Sulecki i W. Morawski - określając istotę tej instytucji, wskazują na przepis art. 3 Traktatu rzymskiego, zgodnie z którym opłaty te nie są nakładane w celu uzyskania korzyści państwa. Powołani wyżej autorzy podkreślają, że opłaty o równoważnym cłom skutku nie mają charakteru dyskryminacyjnego lub protekcjonistycznego, mimo to obciążają one towary niekonkurujące $\mathrm{z}$ towarami krajowymi ${ }^{20}$. Zwolennikiem odmiennego poglądu jest A. Kuś, który twierdzi, że niezależnie od nazwy i sposobu pobierania opłat o równoważnym cłom skutku stanowią one jednostronnie nałożone obciążenie pobierane przy przywozie towarów lub później. Ponadto autor ten podkreśla, że opłaty o równoważnym cłom skutku dotyczą towarów importowanych $\mathrm{z}$ innych państw członkowskich, a nie są stosowane do takich samych produktów pochodzenia krajowego, co pociąga za sobą takie same skutki dla swobodnego przepływu towarów wewnątrzunijnych jak $\mathrm{cło}^{21}$. Podsumowując zaprezentowane podglądy doktryny prawa, należy przyjąć, że opłaty o równoważnym cłom skutku są świadczeniem jednostronnie nakładanym przez związek publicznoprawny, stanowiącym obciążenie obrotu towarowego z zagranicą, przez co wpływają na ceny przywożonych towarów.

W tym miejscu należy zauważyć, że analizowane opłaty mają charakter uzupełniający w stosunku do ceł i zagrażają skuteczności ustanowionego zakazu ograniczania swobodnego przepływu towarów pomiędzy państwami członkowskimi Unii, a także utrudniają handel z krajami trzecimi. Ustawodawca zakazał nie tylko tych środków, które w sposób oczywisty posiadają formę klasycznych ceł, lecz także tych, którym została nadana inna nazwa, a których wykorzystywanie prowadzi do takich samych rezultatów dyskryminacyjnych lub protekcyjnych jak cła. Jak zauważają K. Lasiński-Sulecki oraz W. Morawski, jeżeli popatrzeć na badaną instytucję przez pryzmat obowiązujących przepisów, to należy uznać, że TFUE pod względem funkcjonalności zalicza opłaty o skutku równoważnym cłom także jako świadczenia podobne do ceł. Jednakże analizowana opłata, pobierana w handlu pomiędzy państwami członkowskimi, nie może być opłatą wymaganą na mocy prawa unijnego ${ }^{22}$. A contrario można przyjąć wniosek, że

${ }^{18}$ D. Lasok, Zarys prawa Unii Europejskiej. Część druga: prawo gospodarcze, Toruń 1998, s. 38; wyrok WSA we Wrocławiu z dnia 11 czerwca 2015 r., SA/Wr 797/15.

${ }^{19}$ A. Jędruszczak, Opłaty manipulacyjne na gruncie przepisów prawa celnego, „Monitor Prawa Celnego” 1999, nr 12, s. 510.

${ }^{20}$ K. Lasiński-Sulecki, W. Morawski, Komentarz do art. 30...

${ }^{21}$ A. Kuś [w:] Traktat ustanawiający Wspólnotę Europejska. Komentarz, t. I, Art. 1-60, A. Wróbel (red.), Warszawa 2008, s. 526.

${ }^{22}$ K. Lasiński-Sulecki, Prawna regulacja akcyzy w europejskim prawie wspólnotowym na tle teorii opodatkowania konsumpcji, Toruń 2007, s. 166; podobnie też: 
opłaty o równoważnym cłom skutku mogą zostać ustanowione na mocy prawa unijnego w handlu pomiędzy UE a państwami trzecimi.

Mając to na uwadze, należy podzielić pogląd, zgodnie z którym świadczenie, jakim jest opłata o równoważnym cłom skutku, można scharakteryzować ogólnie jako „środki podejmowane nie w ramach unijnych procedur, lecz na podstawie jednostronnej decyzji państw członkowskich, które niezależnie od nazwy i sposobu ich wprowadzenia wywierają w momencie przywozu towaru taki skutek dyskryminacyjny lub protekcjonistyczny, jaki wywierają cła"23. Podobnie jak cła służą reglamentowaniu tego obrotu oraz ochronie rynku krajowego (unijnego).

W doktrynie ${ }^{24}$ obecny jest także pogląd, że zaliczenie określonego świadczenia do kategorii ceł lub opłat o równoważnym cłom skutkom należy rozpatrywać w oparciu o regulacje Traktatu, przede wszystkim o rozdział dotyczący swobody przepływu towarów. Zgodnie z treścią art. 30 TFUE zakazane jest stosowanie między państwami członkowskimi danin publicznych o równoważnym cłom skutku, ponieważ opłaty - pojmowane zgodnie $\mathrm{z}$ kategoryzacją przyjmowaną $\mathrm{w}$ polskim prawie finansów publicznych $\mathrm{w}$ ścisłym tego słowa rozumieniu mogą $\mathrm{z}$ wyrażonego $\mathrm{w}$ art. 30 TFUE zakazu być wyłączone (aczkolwiek nie wszystkie). Zakaz ten najczęściej jest stosowany wobec podatków, które mogą wywierać skutek tożsamy z cłami. Z tego właśnie powodu niektórzy przedstawiciele doktryny prawa podatkowego posługują się określeniem „zakaz stosowania podatków o skutku ekwiwalentnym z cłami"25. W konsekwencji powoduje to, że cła z łatwością mogą zostać zastąpione przez inne formy danin publicznych, jakimi są podatki. Efekt taki można osiągnąć dzięki wprowadzeniu różnego rodzaju danin obciążających wyłącznie towary pochodzące z innych państw członkowskich. Możliwe jest to poprzez wprowadzenie podatków pośrednich, takich jak np. akcyza czy podatek obrotowy. Są one podatkami cenotwórczymi, gdyż doliczane są do ceny towarów nimi obciążonych.

Odmienny pogląd reprezentuje R.M. Pal. Jej zdaniem nie każde świadczenie nakładane w związku z przekraczaniem towarów przez granice pań-

K. Lasiński-Sulecki, W. Morawski [w:] Akcyza w prawie Unii Europejskiej. Komentarz, K. Lasiński-Sulecki (red.), Warszawa 2014, s. 19.

${ }^{23}$ K. Lasiński-Sulecki, W. Morawski, Komentarz do art. 30...

${ }^{24}$ Prawo podatkowe Wspólnoty Europejskiej, B. Brzeziński, M. Kalinowski (red.), Gdańsk 2005, s. 22.

${ }^{25}$ Por. ibidem, s. 22; K. Lasiński-Sulecki, W. Morawski, Komentarz do art. 30..,; A. Kuś, Swobody europejskie [w:] Prawo Unii Europejskiej z uwzględnieniem traktatu z Lizbony, A. Kuś (red.), Lublin 2010, s. 338. Abstrahując nieco od dotychczasowych rozważań, podkreślić należy, że prawodawca unijny rozróżnia opłaty o równoważnym cłom skutku od podatków, gdyż opłata nie może być pobierana łącznie z podatkami, zatem ta sama opłata nie może w systemie przewidzianym przez Traktat jednocześnie należeć do obu tych kategorii (szerzej zob. B. Makowicz, Opłata o skutku równoważnym do cła $w$ sensie art. 25 WE oraz dyskryminujacy podatek wewnętrzny zabroniony przez art. 90 WE, „Monitor Prawa Celnego i Podatkowego” 2006, nr 10, s. 409). 
stwa może stanowić opłatę o równoważnym cłom skutku. I tak np. do opłat o równoważnym cłom skutku nie należy zaliczyć:

1) opłat składających się na system danin publicznych obowiązujących wewnątrz danego państwa członkowskiego. Opłatą o równoważnym cłom skutku nie jest opłata, która stanowi część krajowego systemu daninowego. Za takim twierdzeniem przemawia treść art. $110 \mathrm{TFUE}^{26}$, który ma wyłącznie zastosowanie dlo towarów pochodzących z państw członkowskich Unii Europejskiej ${ }^{27}$. Z przepisu tego a contrario wynika, że nie znajduje on zastosowania do importu towarów, które dostarczane są z państw trzecich, a to z kolei oznacza, że państwa członkowskie mogą pobierać w obrocie towarowym z państwami trzecimi opłaty o równoważnym cłom skutku;

2) opłat, które pobierane są za usługę wyświadczoną importerowi ${ }^{28}$;

3) opłat pobieranych za działania podejmowane przez państwa członkowskie w celu realizacji obowiązku wynikającego z prawa unijnego, np. opłaty pobierane $\mathrm{z}$ tytułu kontroli zastrzeżonych prawem Unii Europejskiej $^{29}$.

W świetle powyższego wyliczenia konsekwentnie należy stwierdzić, że opłaty o równoważnym cłom skutku nie można utożsamiać z kategorią danin publicznych. Przemawia za tym argument, iż pobierane są tylko od pewnej grupy towarów, w sytuacjach określonych przez ustawodawcę krajowego, a więc nie mają charakteru powszechności, którą to cechę przypisuje się daninom publicznym ${ }^{30}$. To z kolei prowadzi do dalszego wniosku, zaprzeczającemu twierdzeniu, że nie można utożsamiać opłat celnych nakładanych na podstawie krajowego prawa celnego (tzw. opłat wewnętrznych) z opłatami o równoważnym cłom skutku, ponieważ opłaty wewnętrzne danego państwa członkowskiego należy odróżnić od opłat, które zostały zastrzeżone prawem Unii Europejskiej. Stwierdzenie to ma swoje uzasadnienie normatywne nie tylko na gruncie art. 30 TFUE, lecz również art. 110 TFUE. Ten ostatni przepis znajduje zastosowanie wyłącznie do towarów pochodzących z państw członkowskich i może być stosowany do importu towarów dostarczanych z państw trzecich. Pogląd ten znajduje również odzwierciedlenie w orzecznictwie wojewódzkich sądów administracyjnych, w którym

${ }^{26}$ „Żadne państwo członkowskie nie nakłada bezpośrednio lub pośrednio na produkty innych państw członkowskich podatków wewnętrznych, jakiegokolwiek rodzaju, wyższych od tych, które nakłada bezpośrednio lub pośrednio na podobne produkty krajowe. Ponadto żadne państwo członkowskie nie nakłada na produkty innych państw członkowskich podatków wewnętrznych, które pośrednio chronią inne produkty".

${ }^{27}$ Prawo podatkowe..., s. 21.

${ }^{28}$ R.M. Pal, Swobodny przeplyw towarów [w:] Prawo materialne Unii Europejskiej, A. Kuś (red.), Lublin 2011, s. 269.

${ }^{29}$ A. Kuś, Swobody i polityki Unii Europejskiej [w:] Zarys prawa instytucjonalnego Unii Europejskiej, A. Kuś (red.), Lublin 2009, s. 304.

${ }^{30}$ K. Lasiński-Sulecki, W. Morawski, Komentarz do art. 30... 
wskazano, że opłatami o równoważnym cłom skutku są opłaty nakładane jednostronnie z tytułu przywozu lub wywozu towaru, bez względu na wartość lub przeznaczenie towaru. Opłaty o równoważnym cłom skutku muszą jednak mieć związek $\mathrm{z}$ pochodzeniem produktu ${ }^{31}$, co oznacza, że towary muszą zostać wyprodukowane w którymkolwiek z państw członkowskich należących do Unii Europejskiej.

Badając różnice i podobieństwa pomiędzy pobieranymi przez organy celne cłami a opłatami o równoważnym cłom skutku, należy wskazać, że istota i charakter prawny tych opłat stanowił również przedmiot rozważań Trybunału Sprawiedliwości. I tak np. w orzeczeniu z dnia 14 grudnia $1962 \mathrm{r}$. TSUE stwierdził, że opłaty o równoważnym cłom skutku są niezmiennie powiązane z cłem i spełniają rolę opłaty tylko wtedy, gdy realizuje cele Traktatu określone w rozdziale dotyczącym swobody przepływu towarów. Trybunał podkreślił także, że opłaty o równoważnym cłom skutku są to wszystkie rodzaje opłat nakładane jednostronnie przez państwa członkowskie na produkty unijne $\mathrm{w}$ związku z przekroczeniem przez nie granicy, na podstawie przepisów innych aniżeli Wspólna Taryfa Celna. Podnosząc cenę towarów importowanych, wywołują one identyczne skutki dla swobodnego przepływu towarów jak $\mathrm{cło}^{32}$. Z kolei zgodnie $\mathrm{z}$ tezą orzeczenia z dnia 1 lipca 1969 r. opłaty o równoważnym cłom skutku pobierane są niezależnie od ustalonej wysokości, przeznaczenia i sposobu nałożenia, są nakładane na towary krajowe lub zagraniczne $\mathrm{w}$ związku $\mathrm{z}$ wprowadzeniem ich na obszar celny, lecz nie są cłami w wąskim tego słowa znaczeniu ${ }^{33}$. $\mathrm{W}$ innym orzeczeniu TSUE stwierdza, że opłatą o skutku podobnym do cła jest każde obciążenie o charakterze pieniężnym, niezależnie od jego nazwy i sposobu stosowania, które zostaje nałożone jednostronnie na towary w związku z przekroczeniem przez nie granicy, a które nie jest cłem sensu stricto $^{34}$. Natomiast w tezie orzeczenia $\mathrm{z}$ dnia 5 października 2006 r. Trybunał stwierdził, że opłatą o równoważnym cłom skutku jest każde obciążenie o charakterze pieniężnym, niezależnie od tego, czy posiada wartość minimalną i bez względu na swoją nazwę lub zasady stosowania (np. tylko do towarów krajowych lub obcych), o ile jest nakładane jednostronnie $\mathrm{w}$ związku z przekraczaniem granicy celnej przez towar i pod warunkiem że nie jest $\mathrm{ckem}^{35}$.

${ }^{31}$ Wyrok WSA w Łodzi z dnia 1 lutego 2006 r., I SA/Ld 1197/05, LEX nr 895021.

${ }^{32}$ Wyrok z dnia 14 grudnia 1962 r. w połączonych sprawach 2/62 i 3/62, Komisja Wspólnot Europejskich v. Wielkie Księstwo Luksemburga i Królestwo Belgii, ECR 1962, s. 813.

${ }^{33}$ Wyrok z dnia 1 lipca 1969 r. w sprawie 24/68, Komisja Wspólnot Europejskich v. Republika Włoska, ECR 1969, s. 193.

${ }^{34}$ Wyrok z dnia 2 kwietnia 1998 r. w sprawie C-213/96, Postępowanie wszczęte przez Outokumpu Oy, ECR 1998, vol. 4, s. I-1777, LEX nr 111586.

${ }^{35}$ Wyrok z dnia 5 października 2006 r. w sprawach połączonych C-290/05 i C-333/05, Ákos Nádasdi v. Vám- és Pénzügyőrség Észak-Alföldi Regionális Pa- 
Próbę przedstawienia istoty i charakteru prawnego opłat o równoważnym cłom skutku podjęto również w polskiej judykaturze. I tak np. WSA w Warszawie w wyroku z dnia 28 czerwca 2006 r. podkreślił, że opłatą o równoważnym cłom skutku jest każda opłata pobierana w momencie przywozu lub później, w związku z przekroczeniem granicy przez towar - nie obejmując produktów krajowych - powodująca zmianę ceny towaru, posiadająca taki sam skutek dla sprowadzanych towarów z krajów trzecich jak cło ${ }^{36}$.

Mając na uwadze przedstawione stanowiska doktryny i judykatury oraz konfrontując je z obowiązującym stanem prawnym, należy uznać, że do kategorii opłat o równoważnym cłom skutku należy zaliczyć:

a) opłaty za badanie towarów, tj. opłaty związane z kontrolą zdrowotną i sanitarną produktów pochodzenia zwierzęcego ${ }^{37}$,

b) opłaty za testy i badania weterynaryjne przywożonych towarów ${ }^{38}$,

c) opłaty za kontrolę jakości ${ }^{39}$,

d) opłaty statystyczne ${ }^{40}$,

e) opłaty administracyjne za działanie urzędu państwowego w związku $z$ dokonaniem odprawy granicznej ${ }^{41}$,

f) opłaty z tytułu przechowywania towarów w składzie celnym lub wolnym obszarze celnym podczas oczekiwania na zakończenie czynności celnych związanych $\mathrm{z}$ tranzytem towaró $\mathrm{w}^{42}$.

Można dalej uznać, że wspólną cechą wszystkich wymienionych opłat jest to, iż obciążają one towar w związku z przekroczeniem granicy państwa lub regionu wewnątrz związku publicznoprawnego, jakim jest Unia Europejska. W szczególnych przypadkach państwa członkowskie mogą wprowadzić opłaty za dokonane czynności o charakterze obligatoryjnym ${ }^{43}$. Fakt

rancsnoksága oraz Ilona Németh v. Vám- és Pénzügyőrség Dél-Alföldi Regionális Parancsnoksága, ECR 2006, vol. 10B, s. I-10115, LEX nr 193374, pkt 39; podobnie też wyrok z dnia 17 lipca 1997 r. w sprawie C-90/94, Haahr Petroleum Ltd v. Abenra Havn i inni, ECR 1997, s. I-4085, LEX nr 113515, pkt 20; wyrok WSA w Gdańsku z dnia 3 kwietnia 2007 r., I SA/Gd 213/07, LEX nr 1018035; wyrok WSA w Gdańsku z dnia 22 marca 2007 r., I SA/Gd 212/07, LEX nr 1018033; wyrok WSA w Gdańsku z dnia 19 kwietnia 2007 r., I SA/Gd 292/07, LEX nr 1018094.

${ }^{36}$ III SA/Wa 916/06, LEX nr 599493.

${ }^{37}$ Wyrok TS z dnia 7 lutego 1973 r. w sprawie 39/72, Komisja Wspólnot Europejskich v. Republika Włoska, ECR 1973, s. 101.

${ }^{38}$ Ibidem.

${ }^{39}$ Wyrok TS z dnia 26 lutego 1975 r. w sprawie 63/74, W. Cadsky SpA v. Istitutio Nazionale per li Commercio Estero, ECR 1975, vol. 2, s. 281.

${ }^{40}$ Wyrok TS z dnia 1 lipca 1969 r. w sprawie 24/68, Komisja Wspólnot Europejskich v. Republika Włoska.

${ }^{41}$ Wyrok TS z dnia 12 stycznia 1983 r. w sprawie 39/82, Andreas Matthias Donner v. Państwo Holenderskie, ECR 1983, vol. 1, s. 19.

${ }^{42}$ Wyrok TS z dnia 20 kwietnia 1983 r. w sprawie 132/82, Komisja Wspólnot Europejskich v. Królestwo Belgii, ECR 1983, vol. 5, s. 1649.

${ }^{43}$ M. Szpunar [w:] Wolność gospodarcza, Z. Brodecki (red.), Warszawa 2003, s. 106; Prawo podatkowe..., s. 25. 
ten potwierdza orzecznictwo TSUE. Na przykład w ustalającym wiodącym linię orzeczniczą wyroku z dnia 25 stycznia 1977 r. Trybunał sformułował tezę, zgodnie z którą pobierane opłaty nie stanowią opłat o równoważnym cłom skutku, jeżeli ${ }^{4}$ :

a) wysokość opłaty nie przekracza rzeczywistych kosztów poniesionych przez władze administracyjne,

b) opłata w jednakowym stopniu dotyczy całej kategorii towarów,

c) opłata została przewidziana w regulacjach unijnych,

d) opłata służy interesowi ułatwienia swobodnemu przepływowi towarów. Podsumowując problematykę istoty i charakteru prawnego opłat o równoważnym cłom skutku, można ją z całą pewnością określić jako zagadnienie niezmiernie interesujące oraz obszerny $i$ istotny problem badawczy. Poczynione rozważania pozwalają stwierdzić, że opłaty o równoważnym cłom skutku to świadczenia, które nie są daninami publicznymi. Argumentem przemawiającym za takim rozumieniem analizowanego pojęcia jest to, iż opłaty pobierane są tylko od wybranej grupy towarów, przez co nie posiadają cechy powszechności, którą jest charakterystyczna dla tego typu świadczeń. Nakładane jednostronnie przez państwa członkowskie stanowią obciążenie obrotu towarowego z państwami członkowskimi, przez co wpływają na ceny przywożonych towarów. Zasadniczym ich celem jest reglamentowanie tego obrotu oraz ochrona rynku krajowego. Ponadto stwierdzić należy, że regulacje prawne Traktatu o funkcjonowaniu Unii Europejskiej oraz unijny kodeks celny pozwalają na sformułowanie tezy, iż można wyróżnić dwie formy opłat o równoważnym cłom skutku, tj.:

1) opłaty, które zostały wymienione $w$ art. 30 TFUE, co do których obowiązuje zakaz pobierania $w$ transakcjach handlowych pomiędzy państwami członkowskimi Unii Europejskiej, stanowiące dochód tych państw, oraz

2) opłaty pobierane na podstawie unijnego kodeksu celnego, które razem z cłami wchodzą w zakres pojęcia należności celnych przywozowych i wywozowych, a pobierane są $w$ handlu pomiędzy UE a państwami trzecimi, stanowiące dochód Unii Europejskiej i państw członkowskich $^{45}$.

\section{Wnioski końcowe}

Podsumowując wyniki analizy przeprowadzonej w niniejszym opracowaniu, należy przyjąć, iż obowiązujące przepisy pod względem funkcjonalnym wykazują pewne podobieństwo pomiędzy cłami a opłatami o rów-

${ }^{44}$ Wyrok TS z dnia 25 stycznia 1977 r. w sprawie 46/76, W.J.G. Bauhuis v. Państwo Holenderskie, ECR 1977, vol. 1, s. 5.

${ }^{45} \mathrm{Na}$ marginesie prowadzonych rozważań należy zauważyć, że do chwili obecnej prawodawca unijny nie wydał żadnego aktu prawnego stanowiącego podstawę do pobierania przez organy celne państw członkowski opłat o równoważnym cłom skutku. 
noważnym cłom skutku. Są to jednak dwa odrębne świadczenia pobierane od towarów przekraczających granicę państwa i Unii Europejskiej. Istotną, a zarazem charakterystyczną cechą cła jest to, iż pobierane jest przez uprawnione do tego organy celne od podmiotów przewożących towary przez granicę obszaru celnego. Istota cła wynika nie tylko z faktu, że występuje w przypadku przywozu, wywozu lub przewozu towarów przez obszar celny państw niewchodzących w skład UE, ale stanowi również formę regulacji handlu międzynarodowego pomiędzy krajami UE a krajami trzecimi. Nie budzi wątpliwości fakt, że cła są daninami publicznymi pobieranymi na podstawie Wspólnej Taryfy Celnej Unii Europejskiej od podmiotów dokonujących obrotu towarowego z zagranicą.

Cła od opłat o równoważnym cłom skutku wyróżnia natomiast sposób ustalania i pobierania, gdyż opłaty regulowane są poza Wspólną Taryfą Celną UE. Nakładane są jednostronne przez państwo członkowskie Unii Europejskiej w stosunku do towarów przywożonych z innego państwa członkowskiego oraz przez Unię Europejską na towary importowane spoza Unii. Państwo członkowskie nakłada opłaty we własnym interesie, a nie w interesie Unii. Fakt ten powoduje, iż opłaty o równoważnym cłom skutku to świadczenia, które nie są daniną publiczną, a pobierane są tylko od wybranej grupy towarów, przez co nie posiadają cechy powszechności, która to z kolei charakterystyczna jest dla tego rodzaju świadczeń. Jednostronnie nakładane przez państwa członkowskie stanowią obciążenie obrotu towarowego z zagranicą, przez co wpływają na ceny przywożonych towarów. Podobnie jak cła służą reglamentowaniu tego obrotu oraz ochronie rynku krajowego. Opłaty o równoważnym cłom skutku mają w tym zakresie charakter uzupełniający w stosunku do ceł, zapewniając efektywność ustanowionego zakazu. Oznacza to, że powiązane są z instytucją ceł w ten sposób, iż posiadają formę klasycznych ceł, a jeśli nadano im inną nazwę, prowadzą do takich samych dyskryminacyjnych lub protekcjonistycznych rezultatów jak cła.

\section{Bibliografia}

Brzeziński B., Pojęcie i rodzaje danin publicznych [w:] Prawo finansowe, W. Wójtowicz, B. Brzeziński, T. Dębowska-Romanowska, M. Kalinowski (red.), Warszawa 2000.

Drozdek A., Definicja cła - postulat nowelizacji przepisów prawa celnego, „Monitor Prawa Celnego i Podatkowego" 2015, nr 11 (244).

Drozdek A., Charakter prawny cła jako daniny publicznej w krajowym i unijnym prawie celnym, Szczecin 2017.

Drozdek D., Analiza normatywna dochodów budżetowych uzyskiwanych z cet w polskim porządku prawnym, „Prawo Budżetowe Państwa i Samorządu” 2017, nr $2(5)$.

Jędruszczak A., Opłaty manipulacyjne na gruncie przepisów prawa celnego, „Monitor Prawa Celnego" 1999, nr 12. 
Kuś A., Publicznoprawne pozataryfowe i parataryfowe instrumenty reglamentacji obrotu towarowego z zagranica, Bydgoszcz-Szczecin-Lublin 2006.

Kuś A. [w:] Traktat ustanawiający Wspólnotę Europejską. Komentarz, t. I, Art. 1-60, A. Wróbel (red.), Warszawa 2008.

Kuś A., Swobody i polityki Unii Europejskiej [w:] Zarys prawa instytucjonalnego Unii Europejskiej, A. Kuś (red.), Lublin 2009.

Kuś A., Swobody europejskie [w:] Prawo Unii Europejskiej z uwzględnieniem traktatu z Lizbony, A. Kuś (red.), Lublin 2010.

Lasiński-Sulecki K., Prawna regulacja akcyzy w europejskim prawie wspólnotowym na tle teorii opodatkowania konsumpcji, Torun 2007.

Lasiński-Sulecki K., Morawski W., Komentarz do art. 30 [w:] Traktat o funkcjonowaniu Unii Europejskiej. Komentarz, t. I, Art. 1-89, D. Miąsik, N. Półtorak, A. Wróbel (red.), LEX 2012.

Lasiński-Sulecki K., Morawski W. [w:] Akcyza w prawie Unii Europejskiej. Komentarz, K. Lasiński-Sulecki (red.), Warszawa 2014.

Lasok D., Zarys prawa Unii Europejskiej. Część druga: prawo gospodarcze, Toruń 1998.

Makowicz B., Opłata o skutku równoważnym do cła $w$ sensie art. 25 WE oraz dyskryminujacy podatek wewnętrzny zabroniony przez art. 90 WE, „Monitor Prawa Celnego i Podatkowego" 2006, nr 10.

Pal R.M., Swobodny przepływ towarów [w:] Prawo materialne Unii Europejskiej, A. Kuś (red.), Lublin 2011.

Prawo podatkowe Wspólnoty Europejskiej, B. Brzeziński, M. Kalinowski (red.), Gdańsk 2005.

Sawczuk P., Przesłanki stosowania wydłużonego terminu powiadomienia dłużnika o kwocie długu celnego w świetle praktyki orzeczniczej Europejskiego Trybunału Sprawiedliwości [w:] Prawo finansowe w warunkach członkostwa Polski w Unii Europejskiej. Księga pamiątkowa dedykowana profesor Wandzie Wójtowicz, A. Pomorska, P. Smoleń, J. Stelmasiak, A. Gorgol (red.), Lublin 2011.

Szpunar M. [w:] Wolność gospodarcza, Z. Brodecki (red.), Warszawa 2003.

Witkowski P., Instytucje wspólnotowego prawa celnego w międzynarodowym obrocie towarowym, Chełm 2008.

\section{Akty prawne}

Traktat o funkcjonowaniu Unii Europejskiej, wersja skonsolidowana Dz.Urz. UE C 326, s. 47

Rozporządzenie Rady nr 2658/87 z dnia 23 lipca 1987 r. w sprawie nomenklatury taryfowej i statystycznej oraz w sprawie Wspólnej Taryfy Celnej, Dz.Urz. WE L 256, s. 1 .

Rozporządzenie Rady (EWG) Nr 2913/92 z dnia 12 października 1992 r. ustanawiające Wspólnotowy Kodeks Celny, Dz.Urz. UE L 302, s. 1, polskie wydanie specjalne z 2004 r., rozdz. 2, t. 4, s. 307 ze zm.

Rozporządzenie Parlamentu Europejskiego i Rady (UE) nr 952/2013 z dnia 9 października 2013 r. ustanawiające unijny kodeks celny, Dz.Urz. UE L 269, s. 1 ze zm.

Decyzja Rady nr 2014/335/UE, Euratom z dnia 26 maja 2014 r. w sprawie systemu zasobów własnych Unii Europejskiej, Dz.Urz. UE L 168, s. 105.

Ustawa z dnia 19 marca 2004 r. - Prawo celne, tekst jedn.: Dz. U. z 2016 r. poz. $1880 \mathrm{ze} \mathrm{zm}$. 


\section{Orzecznictwo}

Wyrok TS z dnia 14 grudnia 1962 r., w połączonych sprawach 2/62 i 3/62, Komisja Wspólnot Europejskich v. Wielkie Księstw Luksemburga i Królestwo Belgii, ECR 1962, s. 813.

Wyrok TS z dnia 1 lipca 1969 r. w sprawie 24/68, Komisja Wspólnot Europejskich v. Republika Włoska, ECR 1969, s. 193.

Wyrok TS z dnia 7 lutego 1973 r. w sprawie 39/72, Komisja Wspólnot Europejskich v. Republika Włoska, Zb. Orz. 1973, s. 101.

Wyrok TS z dnia 26 lutego 1975 r. w sprawie 63/74, W. Cadsky SpA v. Istitutio Nazionale per li Commercio Estero, ECR 1975, vol. 2, s. 281.

Wyrok TS z dnia 25 stycznia 1977 r. w sprawie 46/76, W.J.G. Bauhuis v. Państwo Holenderskie, ECR 1977, vol. 1, s. 5.

Wyrok TS z dnia 12 stycznia 1983 r. w sprawie 39/82, Andreas Matthias Donner v. Państwo Holenderskie, ECR 1983, vol. 1, s. 19.

Wyrok TS z dnia 20 kwietnia 1983 r. w sprawie 132/82, Komisja Wspólnot Europejskich v. Królestwo Belgii, ECR 1983, vol. 5, s. 1649.

Wyrok TS z dnia 17 lipca 1997 r. w sprawie C-90/94, Haahr Petroleum Ltd v. Abenra Havn i inni, ECR 1997, s. I-4085, LEX nr 113515.

Wyrok TS z dnia 2 kwietnia 1998 r. w sprawie C-213/96, Postępowanie wszczęte przez Outokumpu Oy, LEX nr 111586.

Wyrok TS z dnia 5 października 2006 r., w sprawach połączonych C-290/05 i C-333/05, Ákos Nádasdi v. Vám-és Pénzügyőrség Észak-Alföldi Regionális Parancsnoksága oraz Ilona Németh v. Vám- és Pénzügyőrség Dél-Alföldi Regionális Parancsnoksága, ECR 2006, vol. 10B, s. I-10115, LEX nr 193374.

Wyrok TK z dnia 6 grudnia 2006 r., SK 25/05, OTK-A 2006, nr 11, poz. 169, LEX nr 221524.

Wyrok NSA z dnia 2 grudnia 2015 r., I GSK 793/14, LEX nr 1999860.

Wyrok WSA w Łodzi z dnia 1 lutego 2006 r., I SA/Łd 1197/05, LEX nr 895021.

Wyrok WSA w Gdańsku z dnia 3 kwietnia 2007 r., I SA/Gd 213/07, LEX nr 1018035.

Wyrok WSA w Gdańsku z dnia 22 marca 2007 r., I SA/Gd 212/07, LEX nr 1018033.

Wyrok WSA w Gdańsku z dnia 19 kwietnia 2007 r., I SA/Gd 292/07, LEX nr 1018094.

Wyrok WSA w Warszawie z dnia 28 czerwca 2008 r., III SA/Wa 916/06, LEX nr 599493.

Wyrok WSA w Poznaniu z dnia 28 sierpnia 2008 r., III SA/Po 158/08, LEX nr 501340.

Wyrok WSA we Wrocławiu z dnia 11 czerwca 2015 r., I SA/Wr 797/15, LEX nr 1816998.

Streszczenie

Celem artykułu jest przeprowadzenie analizy ceł i opłat o równoważnym cłom skutku, które pobierane są przez organy celne w związku z przepływem towarów przez granicę celną. Pod względem funkcjonalnym oba typy świadczeń są zarazem podobne, jak i różne od siebie. Istotną, a zarazem charakterystyczną cechą cła jest to, iż obliczane i pobierane jest przez uprawnione do tego organy celne od podmiotów przywożących (wywożących) towary z państw nienależących do unii celnej, na podstawie taryfy cel- 
nej. Przeprowadzona analiza orzecznictwa TS wykazała istotne różnice i podobieństwa pomiędzy cłem a opłatami o równoważnym cłom skutku. Świadczeń tych nie należy zaliczać do danin publicznych. Pobierane są tylko od wybranej grupy towarów, przez co nie posiadają cechy powszechności, która charakterystyczna jest dla danin publicznych. Podobnie jak cła są jednostronnie nakładane przez państwa członkowskie, stanowiąc obciążenie obrotu towarowego z zagranicą, przez co wpływają na ceny przywożonych towarów. Służą reglamentowaniu obrotu towarowego z zagranicą oraz ochronie rynku krajowego. Przeprowadzone badania wykazały również, że opłaty o równoważnym cłom skutku mają uzupełniający charakter w stosunku do ceł. Oznacza to, że opłaty powiązane zostały $\mathrm{z}$ instytucją cła $\mathrm{w}$ ten sposób, iż posiadają formę klasycznych ceł, a jeśli nadano im inną nazwę, prowadzą do takich samych dyskryminacyjnych lub protekcjonistycznych rezultatów jak cła.

Słowa kluczowe: cło, opłaty o równoważnym cłom skutku, organ celny, unia celna

\section{Differences and Similarities Between Customs Duties and Charges Having Equivalent Effect To Duties}

Abstract

This article is aimed at analysing customs duties and charges having equivalent effect charged by customs authorities with regard to the movement of goods through the customs border. The relevant research has shown that the binding provisions functionally show certain similarities and differences between those benefits. The essential and characteristic feature of custom duties is that it is calculated and charged by entitled, relevant customs authorities from entities importing (exporting) goods from countries not belonging to the customs union on the grounds of customs tariff from entities conducting foreign trade in goods. Conducted analysis of the case law of the Court of Justice of the European Union indicated significant similarities and differences between customs duties and charges having equivalent effect. These charges comprise benefits that should not be classified as public levies. They are charged only on a selected group of goods and thus, do not have a universal character, which is characteristic for public levies. Similarly to customs duties, they are unilaterally imposed by Member States and constitute a charge on the foreign trade in goods and therefore, impact prices of imported goods. Charges, similarly to customs duties, are used for regulating foreign trade in goods and protecting national market. Furthermore, the conducted research has shown that charges having equivalent effect to customs duties have a supplementary character with regard to customs duties and thus, ensure effectiveness of an imposed ban. It means that charges have been related with the institution of customs duties in such a manner that they have a form of classic customs duties as well as with those named differently and which lead to the same discriminatory or protectionist results as customs duties.

Keywords: customs duties, charges having equivalent effect to customs duties, customs authority, customs union 